\title{
Sociopolitical Situation in the Northeast Caucasus: Challenges to Nongovernmental Organizations,
}

\author{
Andre Kamenshikov, Vladimir Sukhov, and Mikhail Charaev
}

\begin{abstract}
The authors provide a general analysis of the sociopolitical situation in three basic regions of the Northeast Caucasus, Chechnya, Ingushetia and Dagestan, from the perspective of practical action in the area of humanitarian and charitable activities there. These efforts are directed toward assisting the interaction and implementation of constructive programs on the level of international and nongovernmental organizations, as well as on the level of individual initiatives. Thus, the authors cite examples of organizations which have been successful in these initiatives. They also describe projects that may be implemented in the nearfuture.
\end{abstract}

\section{Precis}

Les auteurs fournissent une analyse generale de la situation socio-politique de trois regions cruciales du Nord-Est Cau-

Andre Kamenshikov is Executive Director of Nonviolence International-NIS, 4 Luchnikov Lane, Entrance 3, Room 2, Moscow 103982, Russia.

Vladimir Sukhov and Mikhail Charaev are activists working with Nonviolence International-NIS, 4 Luchnikov Lane, Entrance 3, Room 2, Moscow 103982, Russia.

This article is an excerpt of the "Brochure on Nongovernmental Organizations of the Northeast Caucasus" reprinted with the permission of the Forced Migration Projects of the Open Society Institute, which published the

whole document in 1997. Full text of the brochure is available free of charge from the Forced Migration Projects, Open Society Institute, 400 West 59th Street, New York, NY 10019, USA, tel.: (212) 548-0655, fax: (212) 548-4676, email: refugee@sorosny.org

As the situation in the Northeast Caucasus, Chechnya in particular, has changed for the worse since the article was written, the authors do not recommend that any organization or individuals go to work there, because of the high security risk involved.

Refuge, Vol. 17, No.2 (April 1998) casien: la Tchetchenie,l'Ingushetie, et Ie Dagestan, dans la perspective de I' action pratique en matiere d'intervention charitable et humanitaire. Ces efforts sont diriges vers une evaluation de 1'interaction et de la mise sur pied de programmes constructifs au niveau des organisations internationales et nongouvernementales, autant $q u^{\prime}$ au niveau des initiatives individuelles. Les auteurs citent donc des exemples d' organisations ayant eu du succes dans la mise en place de telles initiatives. Ils decrivent aussi un certain nombre de projets en preparations.

\section{Introduction}

Disintegration of the Soviet Union,economic crises and the development of many ethnic and political conflicts in the territory of the Newly Independent States (NIS), i.e. former republics of the USSR, have created a new and unexpected challenge to the global community, a challenge, for which it appears to be poorly prepared. The global threat of mutual destruction coming from a nuclear arms race has diminished, but it was replaced by a whole series of destructive processes and crises in many regions of the former socialist camp. These crises take place on a regional level, but have an extremely negative combined influence on the global scale.

One of the most serious consequences of these regional crises is the multimillion flow of forced migrantspeople, whom military conflicts, nationalism, the lack of economic perspectives, and ecological disasters have forced to leave their homes in search of security and a tolerable future.

However, we may note certain positi ve changes, like the fact tha 1997 was the first year after the disintegration of the USSR to begin in a situation when all military conflicts in the Newly Independent States have been formally terminated. ${ }^{1}$ But the probability of renewed military actions remain $\sim$ quite high, especially in Karabakh, Abkhazia, Chechnya and Tadjikistan, where huge problems caused by war remain unsolved such as the problem of hundreds of thousands of refugees, for whom the road to their homes remains closed.

When speaking about the reaction demonstrated by the global community in reply to the arising problems and crises, it is important to note the following:

- First, the rapid development of events and the occurrence ofnumerous crises in the post-Soviet territory was largely unexpected (despite some predictions by various analysts). There was no preliminary plan for a response to these events. As a result, many opportunities for preventive actions against upcoming crises were missed, though they would certainly have been better than responding at a later stage.

- Secondly, today there is at least a formal understanding of the necessity to react to the arising problems, instead ofletting things "burn out on their own." And, though the resources selected for these purposes so far are rather limited, a certain role of in terna tional organizations is felt in practically all conflict zones of the post-Soviet countries.

In terna tional reaction to crises in the Newly Independent States of the former USSR could be formally divided into three levels: ${ }^{2}$

- First, the level of direct interstate relations between the various Newly Independent States and other countries.

- Second, interaction of the NIS with international and intergovernmental institutes, such as the UN, EC, OSCE,NA TO, 10M, ICRC, and their various structures (UNHCR, ODIHR, UNESCO, etc.). 
4)

- Third, the activities of nongovernmental organizations, churches, public initiatives.

This article is directed to assist the interaction and the implementation of constructive programs on the second and particularly on the third level, that is, on the level of international and nongovernmental organizations, as well as on the level of individual initiatives. It includes some general analysis of the situation and the prospects for such activities in the Northeast Caucasus-a region in which today probably the most pain and human suffering of the entire post-Soviet territory is concentrated.

Many of these organizations and groups (and in some cases individual activists) are "insiders" in the situations and must be included as essential components in the framework of any NGO activities in troubled areas. Without their cooperation various programs of humanitarian assistance,trust building, conflict prevention, human and minority rights protection run a high risk of not addressing the most important needs and concerns of the people and communities they are designed to help. Such local groups and organizations can also "open doors" for large international organizations and enable them to carry out their activities in areas, which are impossible to reach otherwise due to bureaucratic obstacles or unacceptably high levels of risk. ${ }^{3}$

However, even simply developing and maintaining contacts with small local NGOs, groups and activists, which is an obvious precondition to any active cooperation, meets with serious difficulties. The greatest of them usually are:

1. The nascent character of most of these groups, which:

- often came to existence as "ad hoc" groups of people, suddenly faced with extreme hardships;

- usually have no clear developed strategy and are overwhelmed by urgent concerns;

- receive support, if any, which is far behind even the immediate needs they face; and
- operate with a staff of volunteers, who often change, creating problems for the continuity of operations.

2. Difficulties in communication: rare and poor phone lines, slow and unreliable mail, absence of local providers of em ail while computers remain relatively expensive.

3. Mistrust-organizations which are based in or have permanent representation and work out of the country's capital are often seen as being somewhat "in bed" with the government, which may be correctly or incorrectly perceived as the main cause of the problem in the first place, 4 especially if the work is going on in a region struggling for independence or autonomy. In situations of military conflicts a major problem becomes the" spy-mania," that often reaches an absurd level. This has to do with the former "Soviet" upbringing of most "modern" NIS politicians as well as with the occurrence in conflict regions of many "security" structures, which need to somehow justify their existence. Negative experience with other NGOs or international agencies may also contribute to this problem.

4. Criminality and problems of personal safety. Robberies, kidnappings, and even murders of the employees of humanitarian missions in conflict zones are unfortunately no rarity and the situation is getting worse. (Chechnya has become especially "famous" in this regard. It is sufficient to remember the wild murder of six employees of the International Committee of the Red Cross.)

5. Transportation, which is often difficult and unreliable. It may become an obstacle for foreigners because of time constraints and the need to obtain special permits to visit certain areas, and for national NGOs because of cost.

Finally, at the other end, there is often a psychological "mind block" that stands in the way of developing direct cooperation between fairly large international agencies and small groups and organizations directly from the troubled areas. The former often tend to disregard the latter (not least, due to lack of information) and either carry out all activities themselves or rely on already well-known organizations. This is often quite costly, time consuming and does not take full ad vantage of existing opportunities.

All these problems result in the fact, that though over the last years quite a few international organizations have gained considerable experience workingin theNISand many national NGOs became fairly widely known for their work on problems of refugees and forced migrants, the activities, of no lesser importance, of many local organizations, groups and individuals from the conflict zones themselves remain either unknown or overlooked.

This is especially true in regards to the Russian Federation with its vast territory, complicated ethnic composition, huge problems and serious distinctions between the situations in different regions.

With the purpose of helping to overcome this lack of information about local NGOs and activists, and in order to analyze possible developments that may cause migration flows in the future, the "Northeast Caucasus NGO Networking Project" was carried out. It included three long missions by the representatives of Nonviolence International (Andre Kamenshikov, Vladimir Sukhov, and Mikhail Charaev) to the regions of the North Caucasus, mainly Ingushetia, Chechnya, and Dagestan, which took place in the fall of 1996. The project has been implemented within the framewor $\mathrm{k}$ of the Forced Migration Projects of the Open Society Institute.

\section{Situation in the Northeast Caucasus}

\section{Conditions and Prospects for Humanitarian and Charitable Activities in This Region}

The Northeast Caucasus is probably the most complex region in the entire postSovietterritory. A complex ethnic composition, a weak economic base in comparison with other regions, a short- 
age of land resources, a problematic historical and cultural inheritance, which includes the tragic experiences of many decades of the Caucasian war and Stalin's deportations of entire peoplesthese are just some of the factors that already resulted in two large-scale armed conflicts in the territory of this fairly small region.

In October 1992, the Ossetian-Ingush conflict took place in the territory of the Suburban (Prigorodny) district ofN orth Ossetia, which cost many hundreds of lives. The Ingush people together with the Chechens had been deported from their homes and sent to Siberia, Kazakhstan and Central Asia on February23, 1944, under a decision by Joseph Stalin. When they were permitted toreturn in 1956, the Prigorodny region and the appropriate part of the city of Vladikavkaz, where they had lived before deportation, remained under the administration of North Ossetia. Instead, two districts were added to the restored Chechen-ingushAutonomous Republic on the northern bank of the Terekriverformer Cossack lands that were slowly populated mostly by Chechens, but not the Ingush.

The conflict between the Ossetians and the Ingush in the Prigorodnyregion left many hundreds dead and up to 70 thousand refugees, predominantly Ingush people from the Prigorodny district who fled to the newly created Ingush Republic. More than half of these people still cannot return to their homes, and often there are no homes to return to.

Nevertheless, the terrible tragedy of the Prigorodny region fades in comparison with the consequences and losses in the course of the Chechen war, which is, probably, the most tragic event in the territory of the former USSR since World WarII.

In the autumn of 1991 a as result of a number of events, which are considered by the Russian leadership today as a coup d'etat, while the Chechens themselves consider them a national liberationrevolution, anew government came to power in Chechnya headed by a former Soviet Air Force General, Djokhar Dudaev. An independent

Refuge, Vol. 17,No. 2 (April 1998)
Chechen state was proclaimed and Chechen armed structures began to form. For three years, the Federal government basically closed its eyes to the events in Chechnya, then it decided to overthrow Dudaev's government. At first, the plan was to do this by supporting opposition forces inside Chechnya militarily and financially, which included sending "volunteers" from the Russian Army to help in this operation. When this attemp collapsed the federal government went on with a full-scale military intervention in Chechnya, which was called" an operation for restoring constitutional order."

The Chechen war, which continued for nearly two years and has been formally declared over in August of 1996, became the most humiliating event for the Russian leadership. Tens of thousands were killed, hundreds of thousands became refugees, cities such as Grozny and Gudermes were partially destroyed and many villages have suffered seriously, quite a few of which were practically levelled to the ground. The same Chechen leadership remained in power that was there before the warexceptfor president Dudaev who was allegedly killed in April of 1996.

Outside Chechnya the cities of Budeyonovsk (in the territory of the Stavropol Region) and Kizlyar (in the Dagestan Republic) became objects of Chechen terrorist raids. And the Dagestan village of Pervomaiskoe was levelled to the ground as a result of the disgraceful operation of "eliminating the terrorists and freeing the hostages." This operation was organized and carried out under the personal control of the Russian minister of Security and resulted in destroying the villC:\}ge, while most of the terrorists managed to escape and even take with them many of the hostages.

The tragic events in the Prigorodny region and in the Chechen republic have caused a noticeable response among various international organizations and agencies, working in the field of humanitarian aid. Many organizations began to work in the North Caucasus, such as UNHCR,ICRC, MSF, 10M, Doc- tors of the World, International Orthodox Christian Charities, the Islamic Committee on Disability and Rehabilitation and many others. The activities of most of these organizations are very important. However there are many problems and difficulties connected to this work as well. The most serious of them concern questions of safety for the members of humanitarian missions (especially in their work on the territory of the Chechen republic) and ensuring that the help provided reaches the groups of the population that are in most need. It is obvious that in solving both of these questions assistance from local NGOs and activists may be of great help.

On the one hand the tragic events "awaken" the activity of many people, who respond to the problems they face. On the other hand the presence of international organizations, the implementation of various assistance programs creates certain new job opportunities, which often become nearly the only ones in an area tom apart by war.

And this leads to some risks. First of all humanitarian missions may find themselves in the situation of a pie, around which there is a fight going on. Second, local people who for a rather long time have been working for them will face a problem of readapting when their jobs will have to go. ${ }^{5}$

Thus, there is a paradoxical situation, on the one hand there is an incalculable number of problems in the solving of which NGOs could play an importan role and on the other hand there is a kind of "unemployment" among NGOs and people who declare their readiness to carry out the largescale programs but have not learned to cooperate with each other and don't have the necessary resources for implementing the projects they declare.

In a situation when there is such a "market" of "unemployed" organizations and activists it becomes quite difficult to "separate the com from the husk." However, the situation can also be seen as an important potential for creating a significant "third sector" in the conflict areas, through which civil 
activity of the population can be expressed and exercised.

Luckily there are quite a few organizations, which already have significant experience of work over the last few years, thus allowing for an estimation of their efficiency. But it is also important to keep in mind that quite often those organizations, which did the most work, cared less than others about documenting those activities and attracting public attention to themselves.

So, in order to select the best partners it is helpful for humanitarian organizations to exchange information between each other. Also it is helpful to be in touch with human rights organizations and journalists who have significant work experience in this area.

Following we provide a brief list of organizations and journalists who, as we know, have spent a lot oftime working in the North Caucasus and therefore may act as consultants for other groups. 6

Organizations

Nonviolence International-New Independent States (NI-NIS), 101000 Moscow, Louchnikov Lane 4, entrance 3, room 2, teL/fax: 2068853; tel.: 351-4855; 206-8618; email: ninis@glas.apc.org, Andre Kamenshikov.

Human Rights Centre "Memorial," tel.: 200-6506, email: memhrcentre@glas.apc.org, Tatyana Kasatkina.

Ryazan Human Rights Society "Karta":7 390000 Russia, Ryazancentral P.O. Box 20, tel.: 0912-7751-17,

email: karta@glasnet.ru. http://ww w.openweb.ru/ryazan http://www.gl asnet.ru/ -hronline/ ngo / proj / rjazan/ memr .htm, Andrey Blinushov.

"Committee of Soldier' sMothers of Russia": 101000 Moscow, Louchnikov Lane 4, apt. 32, tel.: 928-2506, Valentina Melnikova.

"Order of Mercy and Social Protection," 127490 Moscow, Pestelya Street 6B; teL/fax: 9037995, tel. 903-7993, EvgeniyaPoplavskaya.

"The Rightto Life and Human Dignity" Society, 103982 Moscow, Louchnikov Lane 4, entrance 3, apt.
19, tel.: 206-8589; teL/fax: 9639929, Victor Kogan-Yasny.

Centre for Peacemaking and Community Development, tel.: 241-3487; 240-0862; teL/fax: 241-3487, Chris Hunter, peacecentre@glas.apc.org The Organizing Committee of the Agreement "For Peace and Freedom, Against the Bloodshed in Chechnya," Ludmila V ahmina, tel.: 299-1180, fax: 973-2094.

Journalists Who for a long time

worked in the North Caucasus

Alexander Mnatsakanyan, Obshaya Gazeta, tel.: 915-7078.

Yulia Kalinina, " Moskovskiy

Komsomolets," tel.: 946-6293;

Alexander Yevtushenko, "Komsomol

Pravda," in Pyatigorsk tel.: (87900)

59-504.

Andrei Mironov, independent journalist and human rights advocate, tel. 251-8348.

Correspondents of NTV news (Boris Koltsov, Elena Masyuk, Alexander Habarov, Vladimir Luskanov), tel 217-5277, 217-5431, 217-5436.

It is also necessary to note, as a rather important information resource, the Network of Ethnological Monitoring and Early Warning of Conflicts, created by the Institute of Ethnology and Anthropology of the Russian Academy of Science within the framework of the project "Settlement of conflicts in the postSoviet space." It unites by email abou thirty experts from different regions of the NIS including some in the North Caucasus.

When working in the Caucasus in order to get a real understanding of a person's work it is important to keep a very cautious attitude toward any words and stories people tell about their activity. During a conversation it is desirable to stay away from general statements and to find out about the details and specific examples of work. At the same time it is important to keep in mind the fact that people easily become alerted when they are questioned. This is especially the case in Chechnya where there is a huge "spy-mania."
So, during conversations with people engaged in freeing and/ or exchanging prisoners of war, hostages, searching for the "missing" and kidnapped it is important to avoid questions (unless they are absolutely necessary) like "where" and "through whom was it possible to find a person," "who is guilty of his detention," etc. And it is especially important to avoid questions about where and how people were able to gather this or that information.

Obviously there is no unique method of" quality checks" of an organization or a person. Some mistakes are inevitable in any large-scale work. This is important to understand, and not to be discouraged by mistakes but to try to minimize them and their consequences by being cautious and thoughtful. Do not hurry to hire for your operations the first person that you run across, but don't be preconceived about everyone you meet. To be careful in such a complex situation is nat $\}$ lral, and your aspiration to receive additional information should not repel normal people. On the contrary-it may develop a more serious attitude toward your words. And once again, be extremely critical (but in your mind, not verbally) concerning everything you hear.

\section{Chechnya}

\section{General Information}

Chechnya declared its independence from Russia in 1991, and since November 1994, became the battleground of the deadliest war in the post-Soviet states. The war formally ended in the fall of 1996, when an agreement was signed between the Russian Federal Authorities and the Chechen resistance leadership that provided for the withdrawal of all federal troops from Chechnya, presidential and parliamentary elections in the Chechen republic in the near future, and an "uncertainty period" for five years during which a final decision on the political status ofChechnya must be reached. However, the internal situation in Chechnya remains extremely difficult. While there is no strong civil authority in today's Chechnya, the Republic is in the midst of a criminal crisis,

Refuge, Vol. 17, No.2 (April 1998) 
when such events as kidnap pings, robberies, the taking over of people's apartments are common events. The Chechen resistance during the war could be characterized by a large level of independence of its field commanders and by the existence of uncontrolled groups. Today, unfortunately, some members of those groups, as well as others who never were part of the Chechen formations, have formed gangs engaging in criminal activities. ${ }^{8}$ These activities are not contained within Chechnya itself and the surrounding areas suffer from them as well.

Another difficulty is that now, more than before, this violence is often directed against foreigners and representatives of various humanitarian agencies-as a group they are mostvulnerable, and it is possible to extort significantmoney from them with minimal risk.

The most tragic event of this sort has clearly been the terrible killings of six members of the International Committee of the Red Cross (ICRC). Whatever was the reason for this tragic eventwas it just a criminal act, a political act by those circles in or outside Chechnya that are interested in derailing the peace process, the result of a struggle between Chechen factions or whatever else-it certainly had a devastating effect on the perspectives for serious international aid to the area. However, while this event grasped public attention all around the world it is certainly not the first such act of violence against international organizations on the territory of Chechnya. The tragic disappearance of Fred Cuny and four doctors, the kidnapping of two orthodox priests working for International Orthodox Christian Charities (IOCC), the death of a $10 \mathrm{M}$ member, show that violence

._ 3.gainst international humanitarian organizations in Chechnya is a real threat. It is clear that even under the best possible scenario it will take a long time before the newly elected Chechen authorities will be able to put the criminal situation in Chechnya under control.

As for today, most international agencies have pulled out of Chechnya in response to the killings of the ICRC members and it is unclear when they will return.

This tragic situation puts people and organizations that are trying to carry out constructive activities in Chechnya in a dilemma, because continuing their operations in the current environment is a great security risk. To ignore this may serve as a kind of encouragement for the continuation of violence against such organizations and people, while pulling out at this moment may significantly aggravate the already extremely difficult situation for the people of Chechnya and thus, considering the availability of weapons, the extreme deprivation of so many people, the lack of sources of sustainable income will make it even more difficult for any new leadership to take control and crackdown on crime.

One of the approaches that is being tried out by some organizations today in response to the difficulties they encounter is to continue programs aimed to help the Chechen population (mainly refugees) outside Chechnya, in the neighbouring regions. However this approach has some serious setbacks. It creates incentives for refugees to stay outside Chechnya for a longer time than is necessary, or requires them to travel back and forth. For people from the southern regions of Chechnya who are working on rebuilding their houses (the war in those areas was most devastating) it is particularly difficult to benefit from these programs. And this approach irritates the local population in the regions surrounding Chechnya (during field trips we have heard complaints both in Ingushetia and Dagestan aboutthis). Both these republics have immense problems of their own, Ingushetia still has nearly forty thousand refugees from the Prigorodny (Suburban) district of North Ossetia who left after the conflict in 1992.

This extremely difficult situation more than ever before requires search for new approaches to the activities of various agencies, organizations and individuals, who would like to have a constructive impact on the development of the situation in Chechnya. We, therefore, propose a shift in the way different charitable and humanitarian programs are being carried out. We suggestthat:

- There be a shift from emergency relief to programs which assist in the rebuilding of a sustainable economy.

- There be a shiftfrom fairly large programs managed by permanent international staff to a larger number of smaller programs carried out mainly by local people and organizations.

- Various international agencies cooperate in developing a basic infrastructure for their operations and, what is more important, for the successful work of local organizations. First of all that would mean opening opportunities for cheap and fast communications available for small local based NGOs.

If such changes in approaches take place they will significantly reduce the risks that representatives of various organizations expose themselves to when they set up offices and place staff in Chechnya on a long term basis. Certainly this approach will require regular field trips to the area to supervise and monitor the implementation of various projects. However, it is possible to further reduce the risks, and significantly lower the costs if some of the monitoring job could be carried out by human rights and other organizations that will continue their visits to Chechnya anyway.

\section{Problems with Communication}

If we want to successfully and regularly communicate with an NGO, notto mention carrying out any joint programs, we must achieve the following:

1) Provide the means to communicate regularly.

2) Initiate contacts.

3) Generate interest for continuous communication and information exchange.

4) Assist in developing perspectives for future programs and actions and in allocating necessary resources.

5) Encourage continuous follow-up on the implementation of the agreements made and plans designed. So far there are no regular phone lines operating in Chechnya. Satellite phones 
are the most reliable way to communicate but their costs are high. As for cellular phones, there is a company that provides such a service in Grozny, but so far they have set up only one transmission cell, so the phones are operable in Grozny and the nearest villages in about a 15 mile radius. In other places extra equipment must be set up, for example, in the Chechen town of Sernovodsk it is possible to set up an antenna that will make it possible to establish communications through a cellular phone service in the Ingush city of Karabulak about 20 miles away.

It is important to understand that making communications available at some location does not solve the communication problems in itself. However it is certainly a precondition to every successful cooperative project, so this objective should certainly come first.

In order to achieve this objective it seems possible to support and promote some of the Chechen based NGOs to focus precisely on providing communication to other NGOs and activists in the area and to encourage them to communicate more actively with organizations outside Chechnya.

As a first step it is important to organ-: ize a few centres where NGOs and activists could use email in order to communicate. Because most people don't have any experience with emailit requires finding or training people who could take upon themselves the task of typing messages into a computer and managing the email communications for the others. If email servers will be opened in the near future (so far there is a slight possibility of that and only if the overall situation will slowly improve) it would be possible to simply cover the costs of their services for certain local NGOs and groups. It is also possible to prepare brief information leaflets on "how NGOs can communicate" that could be distributed through the current Chechen authorities who are responsible for registering NGOs as well as through the local press.

However it is important to understand that written communication is generally not an element of common culture in post-Soviet states. People, unlike in the Western states, are not used to relying on letters for communication between themselves and especiallyin business communications. Nor are they used to writing proposals or developing precise work plans. That is why it is important to allocate people who will focus on helping others to formulate their ideas and plans into a form that will be acceptable for international organizations and Western foundations. These same people would also be able to assist others by distributing information materials about international organizations and foundations.

Technical assistance, training and financial support for such liaison organizations could be provided by international organizations, agencies and foundations.

Technically speaking every such "communication group" would need the following:

- A staff of 2-3 people including at least one person who understands computers and communications (Projected cost: \$8,000-12,000 per year).

- A computer, printer, modem (Projected cost \$2,000).

- Technical means for communicationcellular phone or a microwave link to a communication centre (Projected cost for first year of operation \$ 7,000 , less for following years).

- Acartobeabletotravelandcommunicate with various organizations in different locations (Projected cost $\$ 3,000)$.

- Finances to cover operating costs, Le. various bills, gasoline, repairs, etc. (Projected cost \$2,400).

The total cost of such a project will amount to somewhere around $\$ 24,000$ to $\$ 28,000$ a year (not including training, preparing materials for distribution and other expenses that can be included in the operating costs or considered contributions from other organizations). It would be best to organize three such points-one in Western Chechnya covering such areas as Sernovodsk, Samashki, AchkhoiMartan, Gekhi, UrusMartan, Znamenskoe etc.; one in Grozny-for Grozny and Central Chechnya includ- ing such towns as Atogi, Tolstoi Yurt, etc. and one in Gudermes or Shali for Eastern Chechnya.

On the part of international organizations, developing such a communication network through local organizations will require active and regular sharing of experience and information about plans and projects and about local organizations involved in them.

Developing such a program requires a significant investment but in the long run it may be very effective and save far greater resources as it will allow to replacement of some costly field trips with a system of regular monitoring of the activities of the NGO sector in Chechnya. It is also important to consider that when there is a constant struggle for resources it may be difficult to get information from some NGOs about others, especially if those others are seen as possible competitors for funds. That is why it is important to have organizations whose main objective is precisely gathering information and assisting communications with such groups and therefore are not themselves afraid of being left behind in the struggle for resources.

There are obviously setbacks to such an approach as well. First of all it is extremely important to have reliable, well-trained and honest people involved in such projects. In a situation when most international organizations have pulled out, their role becomes very important.

\section{From Emergency Relief to Support for Long- Term Programs and Economic Reconstruction}

Today the chances for a peaceful settlement of the Chechen crisis are higher than ever since the beginning of the war/, • though they are still far from being definite. Immediate humanitarian needs in Chechnya remain immense.

However today's situation, which can be characterized as "a chance for peace" requires new approaches, such that would create a "peace dividend" for the population and help people to

Refuge, Vol. 17, No.2 \{April 1998) 
return to peaceful life. These could be such actions as:

- helping to set up small enterprises, especially those that would bring immediate benefits to the population; and

- assisting local initiatives, aimed at dealing with the legacy of the war such as setting up orphanages, rendering psychological support to people who lost their family members,etc.

What programs of this type could be carried out in today's Chechnya? One area that seems to be a good place to focus such efforts on is the food industry. Obviously, food is the number one human need. So far hunger has not been an extremely serious problem in Chechnya only because of the high level of cooperation and strong family ties in the Chechen society.9 However cooperation does not solve the problem when there is a general lack of resources for human life. Agriculture in Chechnya was in a poor state before the war and by today it has been devastated. Many fields remain unavailable for agricul- . ture because of land mines. And, where there still is agricultural production, there often is a lack of equipment for food processing. That is certainly an area that needs support. One of the practical ways of helping would be setting up fairly small mills in areas wherepeopIe still produce grain, but are not able to grind it. In places where old state and collective farms remain, they often simply hand over whatever they produce to the people. For example in the Chechen city ofSernovodsk practically each family has its own reserve of grain. Setting up a chain of mills in such locations would benefit the population in many ways.

First of all it will make flour much cheaper for the people. Today people need to travel twenty to fifty kilometres or more to grind their grain. This is ex pensive and often too expensive for many. Plus that, the existing facilities are not large enough and people need to stand in long lines, signing up a month or so in advance, to get their grain processed. Buying bread is even more expensive, a loaf costs about 2,000 ru-

Refuge, Vol. 17,No. 2 (April 1998) bles-about U.S. \$0.35 and many don't have the money for that. People can prepare their own traditional bread, as well as other foods out of flour if they have it. This is why a set of mills will improve the food situation for those in greatest need. Right now such a project is being investigated for Sernovodsk, a town on the western border of Chechnya, which the federal forces attacked in March of 1996. During that time the village suffered significant damage. Today it could be considered one of the fairly safe areas in the Chechen republic. If the project of setting up the mill in Sernovodsk will be successful, it will also benefit the nearby village of Samashki, which twice during the war suffered devastating military operations in which hundreds of people were killed. The mill project for Sernovodsk could also serve as an example of how such operations can be managed through local NGOslO and therefore it has a good chance of bee oming the first link in a chain of similar projects throughout Chechnya. Mills are obviously not the only small enterprises in the food industry that could be effective ways to support small business.

Other programs could include supplying bakeries or, for example, supplying the equipment necessary to bottle mineral waters, which Chechnya has. Some of these waters are known to have a very good effect in the treatment of certain illnesses and they could be exported to areas outside Chechnya. ${ }^{11}$

Another area where it seems possible to assist small enterprises in Chechnya is the construction ind ustry. Hundreds of thousands of people had their homes destroyed or seriously damaged during the war. In the southern areas there are villages that were literally flattened. Today people are trying to pull their lives back together, rebuild and repair what was destroyed. There is a great need for a construction industry especially for small factories, which could produce bricks and other building materials. However, this requires larger investments than similar small business projects in the food industry and it is important to be extremely careful in implementing any such programs.
One thing that is important to clearly understand, is that neither today nor in the foreseeable future will there be any guarantees for the return of investments in Chechnya. ${ }^{12}$ The best approach is to consider any. assistance program for Chechnya as charity, and if it happens to be possible to get a return-well, all the betterfor you.

\section{Who Are Your Partners?}

Since the main goal of this paper is to give specific information about NGOs in the Northeast Caucasus, we will provide information about different Chechen NGOs and activists. It is important to understand that this information is far from complete. In fact, a complete list of NGOs, activists and various civil initiatives does not physically exist. The situation in Chechnya is changing so rapidly that an attempt to provide a full descriptive analyses of these various groups and peoples is almost impossible.

However, there are groups and organizations that we got to know and to cooperate with during our many visits to Chechnya (since August 1994). Where possible we tried to indicate perspective programs for each organization we were in contact with, and define the most immediate needs for the organization's development.

One thing has to be kept in mind-the reliability of mail to Chechnya is slightly greater than to Mars. Looking up a house in Grozny according to its street address is often possible, but sometimes you may have problems finding the proper street when half of the houses that once lined it have ceased to exist. Inhabitants of the city also prefer not to . use the official street addresses but nicknames of the city's districts, which often have no relevance to signs on the map.13 If you are asking directions in a village you never hear the street address at all (I actually suspect that many people simply don't know their own street address). But you get good directions like, "You go through the central market (which may be a couple of miles long) then take the road on your right, when it turns left you see a school on the right 
side, take the lane opposite it and turn the comer two houses after the broken tractor-or just ask anyone for me."

\section{Nongovernmental Organizations and Activists in Chechnya}

Society "For Peace and Human Rights"

Headed by Shaman Adaev (Shaman Adaev , Leila Tsoroeva, and Andre Kamenshikov).

Address: Chechen Republic, Sernovodsk, Sovetskaya Street, house 51.

\section{Infonnation}

Shaman Adaev, the organizer of this group, is a young Chechen who from the beginning of the war was involved in helping correspondents and human rights workers gather objective information about the events in Chechnya. Many Russian and international correspondents, human rights and humanitarian workers, members of the Human Rights Centre "Memorial" and of Sergei Kovalev's Commission on Human Rights, deputies of the Russian State Duma and many others have used the help of Shaman during their work in Chechnya. At certain times during the war, Shaman's family house in Semovodsk practically turned into a press Centre from which came a large share of the news about the Chechen war. Besides that, Shaman himself did extensive work on gathering information about human rights abuses during military operations in Sernovodsk (his family's house was damaged in those events) and neighbouring Samashki He has helped other local activists begin their work. He distributed humanitarian aid and money received from different international organizations to the families in his village who suffered the most.

\section{Perspectives}

Shaman and his family can certainly be considered key people for various charitable and humanitarian operations in Chechnya. However the society "For Peace and Human Rights" seems to be the most suitable NGO for two specific projects-setting up a mill, as one of the first programs aimed to rebuild small enterprises and organizing a Centre for communications with nongovernmental organizations of Chechnya and Ingushetia.

The location of Sernovodsk allows one to establish phone communication via the transmission centre in the Ingush town of Karabulak, about 15 miles away. If that is done, email is no problemShaman already has a computer and a modem and is computer literate.

Another requirement is a newer carthe one that is being used now is totally unreliable.

With the extensive contacts of Shaman and his family both among Chechen and Ingush organizations ${ }^{14}$ as well as among Russian and international human rights activists and journalists, his society is in a unique position to become a communication centre with other Chechen and Ingush NGOs.

\section{Chechen Branch of the Women's}

Committee of the North Caucasus (Also-Chechen Branch of the Centre for Peacemaking and Community Development)

Address: Chechen Republic, Grozny, Staropromyslovskoe Shosse (Zavety Ilicha Street), house no. 129, apt. 43 ("GorodokMayakovskogo").

\section{Infonnation}

This organization is the Chechen division of the organization Women's Committee of the North Caucasus that is headed by Svetlana Umarovna Alieva. She is a writer that focused on studying and highlighting the tragic stories of Stalin's deportations of various ethnic groups. The organization in Chechnya is headed by Zainap Gashaeva and consists of four Chechen women.

The main objective of the group when it was organized in the beginning of 1995, was to document and expose facts of serious human rights violations committed by the federal forces in the process of the Chechen conflict. The group was mainly supported by the Moscow based Centre for Peacemaking and
Community Development, which was organized by two representatives of the British Quakers-Chris Hunter and Patricia Cockrell. This group gathered extensive video material during the war (over 100 videocassettes and many photographs). Members of the group went on many speaking tours to Western countries ${ }^{15}$ where they presented information on the Chechen war and lobbied international organizations to put pressure on the Russian government to end the hostilities. They participated in various antiwar actions like the Women's March in the Spring of 1995 and many demonstrations and pickets both in Chechnya and in Moscow. They distributed small quantities of humanitarian aid (warm clothes ) received from Oxfam and from Saudi Arabia.

Recently the Centre for Peacemaking and Community Development opened a branch in Chechnya at the above address. The contact people for it are Zainap Gashaeva and Adlan Adaev. The actual office is located at the "Orgtehnica" club near the factory of Electrical appliancesalso on the Staropromyslovskoe Shosse in an area that is called Katayama.

\section{Perspectives}

Today the group is in the process of readjusting and finding its place in the postwar situation. It is at present involved in the serious project of setting up a centre forrehabilitation of children in Chechnya, initiated by Chris Hunter. However, while this may require the participation of the group in solving logistic and organizational questions, it seems best that the actual management of the project be handled by the teachers and doctors of the former children's sanitorium that is the projected location of the rehabilitation centre. As for the group, the best option seems to be work on programs which involve preparing lists of the people and families who suffered especially severe hardships as a result of the war, who lost their family members, etc., and rendering psychological and some humanitarian aid to these people and families (this aspect of work was one of the ini-

Refuge, Vol. 17, No. 2 (April 1998) 
tiatives of the group itself, and themembers of the group have already done some work in this direction). In order to work further on this the group needs money for salaries and for transportation around Chechnya, a computer and some training in using it to set up a database, as well as in accounting skills.

\section{Public Organization "Chechen Mothers"}

Headed by Madina Magomadova. Address: Chechen Republic, 364000 Grozny, Zavety Ilyicha Street, house 187, apt. 36.

Contact in Moscow-through the Committee of Soldiers Mothers of Russia, 103982 Moscow, Russia, Louchnikov Lane, hA entrance 3, room 32.

\section{Infonnation}

Since January 18th 1995, Madina Magomadova has travelled to Grozny in an attempt to find her brother, who disappeared at the beginning of the war. She has not been successful in this task, but in the process has met many other women-from Chechnya and mothers of soldiers from different areas of Russia, who were in a situation similar to hers. So she began advocating on the part of these people, writing letters of inquiry to various official institutions of the Russian Federation (often with the help of deputies of the Russian State Duma). Since the summer of 1995 Madina became a member of the Commission for the search for missing people which functions under the auspices of the OSCE mission in Chechnya.

Today, besides the Committee of soldiers mothers of Russia, Madina is cooperating with the organization "Lawyers without Borders." In the process of he rwork,Madina was able to find nearly 50 Russian servicemen who were taken as prisoners of war by the Chechens and negotiate the release of many of them. In some cases these were soldiers officially pronounced dead by their military commanders. In finding Chechens, Madina had less successshe was able to find only bodies of people who were killed in the course of the war. It has often been hard to identify these corpses.

\section{Perspectives}

At this point, though the war has been declared over, many hundreds of both federal servicemen and Chechen fighters who were captured during the fighting still cannot return to their homes. An agreement was reached and included in the peace accord that all people "forcibly held" by both sides will be released on the basis of" all for all" without any preconditions, but in reality the process of their release is taking place very slowly and with great difficulties. Madina is convinced that many Chechens, who were detained by the federal troops during the war, have since been given sentences on various criminal charges. That is due to the fact that according to the official Russian position there was no war in Chechnya but simply a police operation to restore constitutional order. So legally, there cannot be any prisoners of war. Today it is very hard to locate the Chechens who were sent to different penitentiary facilities all around Russia and therefore are not in the hands of the military commanders who, according to the agreements, are formally responsible for their release.

On the Chechen side, there also are great difficulties in finding the Russian prisoners. Some of them are located in official prisoner camps, others are held by separate families, which demand that they will exchange the prisoner only for their own missing relative. Often money is demanded as well. Another serious problem is the continuing hostage taking crisis in Chechnya when both Chechens and people from other areas (for example, builders from other regions who were working in Chechnya) are kidnapped for various demands, usually-financial. All of this creates a great need for the kind of work Madina Magomadova is involved in. Unfortunately,itdoesnotseemnecessary for her group to search for new kinds of activities in the current situation-today's situation in Chechnya suggests that their work will be required for a long time to come. What she does need is some financial and technical as- sistance for her work-money to travel, a computer, money to pay a secretary, etc.

\section{Republican Child Creativity Centre}

Address: Chechen Republic, Grozny, Krasnoznamennaya Street 10.

\section{Infonnation}

Unlike many other groups that were created recently as people's response to the hardships they experienced during the war, the Child Creativity Centre is an old organization staffed by people who used to work in the former "Children's Palace" (or the "Pioneer Palace") which was the centre for children's extra-curriculum activities (dancing, painting, sewing etc.). The old threestory building of the Palace which was one of the nicest buildings in Grozny was seriously damaged during the war and needs a major repair job before it may operate. Today the Centre has a few rooms in what formerly was a nursery school and it also uses the facilities of a nearby school.

Today the Centre for Child Creativity is, if not the only, certainly the largest $\mathrm{NGO}$, that is working with the minds and spirits of children who lived through a war.

Taking into account today's Chechen realities this work is hard to overestimate. What is most remarkable is thatthe work of this organization has continued throughout the past two years-except for two interruptions caused by the fighting in Grozny. Of course, the scale of activity has dropped drastically compared to what it was before the war. Of nearly 250 clubs and sections where almost 3,000 children participated, today about 20 clubs are left, attracting about 400 children. But the Centre continues to function and not only helps the children that attend its programs, but is producing methodological papers on how to organize similar activities, to be distributed among schools and child centres in other districts of Chechnya.

The people working in the Centre are especially proud of the children ensemble "Lovzar" headed by Mr. Taklaev, 
which has performed not only in Chechnya, but in other republics of the North Caucasus, Moscow, and Bulgaria as well.

"When we gathered after the fighting near our former palace and realized that we could not use it anymore" -says Janna, the head of the Centre-flour children began to dance right in the street." People around were surprised. They had not seen dancing for many months and could not understand why we should be dancing in the middle of a destroyed city. But with our dance we've shown, that life goes on, that our spirit is not broken and we will live and continue to do what we've been doing no matter what."

\section{Perspectives and Needs}

The Child Creativity Centre has proven its potential not only to survive, against all odds, but to grow, now that the war is over. The need for the kind of work it does is tremendous. Any help will mean a lot for bringing the children of Chechnya back to a peaceful life.

The Centre needs help in repairing a hall for the children to rehearse and perform in, suites for children's clubs, money f9r travel (the Centre tries to organize summer vacations for the children in other regions), and much, much more. One relatively inexpensive way to help would be to supply a photocopy machine to be used for producing materials to be distributed among schools and centres for extracurricular activities around Chechnya.

Another way to help the Centre for Child creativity could be to develop some fund-raising programs in cooperation with it-such as producing postcards with the pictures children draw, or organize fund-raising tours with performances by the children's ensemble.

\section{Council for Religious and \\ Confessional Affairs of the \\ Chechen Republic}

Headed by Sumbulatov Aguzar Alievich. Address: Chechen Republic, Grozny, Mayakovskogo Street 86 " A," apt. 44.

\section{Infonnation}

The Council was created before the war, during "Dudaev's regime." It has functioned throughout the events of the last years. It has two branches-Christian and Moslem. It is involved in several areas of work:

- Developing cooperation between the different religious confessions of Chechnya, propagating mutual understanding between people belonging to different religions and denominations.

- Humanitarian aid through the churches to people in greatestneed.

- Restoring churches, mosques; reviving the activities of the various religious communities.

- Helping in religious education, sending people to religious educational institutions, making religious literature available for the public.

- Organizing a TV Centre and preparing programs for the local TV, creating a press-Centre.

The Council has prepared the text of an inter-confessional agreement, that includes quotations from the Bible and the Koran, proving the close relationship between Christian and Moslem religions, and voices the need for developing positive relationships between people of all denominations. The Council is cooperating with the youth movement "Djamagat," which announced its desire to protect the non-Muslim population of Chechnya from criminal activities.

Throughout the war, the Council for Religious and Confessional affairs has participated in the delivery and distribution of humanitarian aid, mostlyfrom Churches and ChurchNGOs (such as "Caritas"). For example, recently the Council received ten tons of hum ani tarian aid, which was distributed among hospitals throughout Chechnya. The Council has assisted the work of the head of the Orthodox community in Grozny, who created a shelter for people (mainly the elderly) who lost their homes.

The Hadjiev government, when it was in power (in the first half of 1995), helped the Council with six billion ru- bles (about 1.2 million dollars). Most of this money was allocated to support the reconstruction of churches, mosques and other religious facilities. The Council does not have the funds to continue this work, but it is hoping to resume it when funding becomes available. Before the war, Chechnya had six churches, 420 mosques, and a few prayer houses

There are plans to organize religious lessons in the schools. People have been sent to Arab countries to get religious education. There are plans to recommend people for religious schools in Russia as well. The Council is supporting a program to create a German religious and cultural Centre. A library is being created with religious literature and many books have been distributed among the public.

The Council hopes to organize a set of TV programs, which will educate the population about various religions and confessions, and expose the common roots and principles among them. This is important to help ensure interethnic peace and cooperation in Chechnya.

\section{Perspectives}

Taking into account the wide scope of the Council's operations, it is hard to say what kind of support is not needed by it. However, in a situation in which there are limited resources, we would recommend focusing on the following:

- Supporting the media programs that the Council is ready to prepare. In today's Chechnya, with the heavy legacy of the war and uncontrolled crime, it is essential for people to hear, read and see programs that focus not on the negative, but on the positive, not on the past, but on the future. And taking into account the low level of education of the population, the spread of some ratherprimitive understanding of Islam. ${ }^{16}$ It is important for people to understand that religion must not separate but unite people. (What is most needed atthispointisagood video camera.)

- Some resources need to be found for a few salaries for people, working in the Council (2-3 at least). So far, most 
of the work is carried out by volunteers but this cannot last forever.

- Assistance with providing a vehicle. Without one, the ability of the Council to keep in touch with people and organizations around Chechnya is very limited.

- Help in restoring the office of the Council. It is iocated on the" groundfloor" -basically, a basement of an apartment house and is in very poor condition.

\section{Revival Fund of the Chechen Republic}

Headed by Shamil Beno, a Chechen born in Jordan who was the first Minister of Foreign Affairs of Chechnya under the presidency of Djohar Dudaev. Address: Chechen Republic, 346047 Grozny, Hankalskaya Street 78. Cellular phone: 903-30-77 $7^{17}$ (area code from Moscow: 8-2 from other regions ofthe CIS: 8096; in Moscow fax: 928-48-73).

\section{Infonnation}

The Fund was created in the middle of May 1995 by a group of people who had already been involved in charity and humanitarian assistance, helping people who suffered during the war. The group of founders of the organization (nine people) included two bankers, specialists in construction, an economist, two scholars and a journalist. Besides humanitarian aid, members of the Fund actively participated in different peacemaking and mediating initiatives, trying to assist in putting an end to the hostilities which caused the problems in the first place (participated in monitoring negotiations on behalf of public organizations proposed strategies to improve the peace process, etc.).

In 1995 and in the beginning of 1996, the Fund assisted thirteen families with a total sum of sixty million roubles (nearly one thousand dollars). Unlike most other organi ations, the Fund tries not to help many with a little, rather seriously support a few families and help them adjust to new conditions. This includes providing substantial financial aid, providing apartments, purchasing small street-shops so people could earn a living for themselves, etc.
At present the fund is looking for people that could become its trustees and support its activities. Negotiations about that were held with the head of the Union of Industrialists and Entrepreneurs A. V olski, a representative of the President of Tatarstan (the Tatar Republic) and others. These trustees would control how the help they provide is being used while the Fund will provide logistic and organizational support. The Fund is managed by the Council of the Fund. Its highest body is a Conference of the Members of the Fund. Once a year, the Fund is supposed to inform the public about who has been providing aid via the Fund, who has received this aid, etc.

\section{Perspectives}

Strong points of the Fund is its clear organizational structure, its good ties on various levels both in Arab countries and in Russia, its through control over the use of resources and its focus on substantial aid that may really help change peoples lives for the better.

At this point the Fund focuses on the following programs:

- Creating an orphanage. There are plans to open an orphanage for about 250 children that lost their parents during the war. A place has been located for it in the Staraya Sunja village and there is an agreement with the local administration. Agreements have been reached with Jordanian organizations and the Mufti of Chechnya Kadyrov.

- Registering people who got injured during the war. The Fund cooperates in this task with the Islamic World Council on Disability and Rehabilitation that will accumulate the information gathered and agreed to finance the project. The work will be carried out with the cooperation of the societies of the disabled in the various districts of Grozny and Chechnya, the local administrations, etc.

- Humanitarian assistance during the winter. A preliminary agreement about this was reached with the Egyptian Embassy. Egyptian representatives distribute the aid, while the Fund will collect information about the people in most need, provide transportation, take responsibility for security, etc.

- Creating an ophthalmological clinic in Grozny, Realizing how expensive it is to send people to get medical treatment abroad, the Fund is trying to support the creation of medical centres in Chechnya.

The Revival Fund of the Chechen Republic also seems to be a good organization to approach with various projects aimed to set up small businesses and enterprises. Of the most important needs the Fund needs two trucks: one small one (around 1.5 tons) for use in the city, and a larger one for delivering significant quantities ofhumanitarian aid to different locations in Chechnya. ${ }^{18}$

\section{Centre for Protection of Rights and Culture}

Headed by Elhanov Islamjan Israilovich. Address: Chechen Republic, Grozny, Michurina Street 105.

\section{Infonnation}

The Centre for Protecting Rights and culture was registered in September of 1995 (The work actually began in the first months of 1995). The Centre was organized by three people known in the Republic-Islamjan himself, SaidMagomedHasiev, Bisultanov Apti. The focus was to protect both human rights and Chechnya's cultural institutions, which have suffered great damage during the war. At present t.. ere are two major programs being carried out:

- "Victims of the war" -includes preparing lists of victims of the fighting in Chechnya. A questionnaire was developed for this purpose. The Centre also plans to gather information about human rights violation during the war, about" missing" people, and attempts to trace them, etc. At this point the Centre has a list of around one thousand people, mainly Chechens who were arrested during the war.

- "Reviving cultural life. " This is seen as the main focus of the Centre. Dur- 
ing the fighting archives were burned, libraries and monuments destroyed etc.

Right now there are attempts to restore a library. The Centre was able to negotiate an agreement that 100,000 books will be sent to Chechnya.

\section{Perspectives}

The Centre for Protection of Rights and Culture is a rare example (perhaps the only one so far) of a Chechen organization that was able to formally apply and receive a sizeable grant (over $\$ 50,000$ ) from the Moscow-based Open Society Institute. The main purpose of that grant is to support the "Victims of war" program. The Centre also may need help in creating a computer database for holding and using this information.

\section{Plans for Organising an Orphanage \\ in Achkhoi-Martan for Chechen Refugees}

Contact: Vaha Zavliev, in AchhoiMartan, and ask for directions.

\section{Infonnation $^{19}$}

Five years ago there was a facility in Achkhoi-Martan for children who either lost their parents or for various reasons couldn't live with them. Only one school functions on its territory. During the last four years an enthusiastic person from the local community has been developing plans to revive this facility. He wants to unite in one complex the former orphanage, the building of a former teacher's training school and two children's camps (former pioneer camps) near the town. He believes that this facility could hold up to 3,500 children of the ages from six to seventeen. Besides places to live and study the facility would also include a farm where the children could work and produce agricultural products to feed themselves. However, more or less serious repairs must be done on all the buildings of the selected facilities before they can operate.

\section{Psychological and Security Aspects of Work in Chechnya}

In the process of preparing and carrying out various humanitarian projects, con- sidering the high security risks in today's Chechnya, it is helpful to focus on towns and villages where these risks are significantly less than in other areas or in Grozny. Today no place is safe but the security situation varies a great deal from place to place. It is generally worse in the cities and differs a lot in other areas.

Another area which poses a great risk to visitors is the southeast of Chechnya. In any case, before starting any serious program it is important to get the approval of both the central authorities in Grozny, the local administration and field commanders. Negotiating this may require some skills. On the one hand it is importantto generate some interest in the work you or your organization is proposing and to show what benefits that would bring to the area. On the other hand, however, it is important to be very careful in "opening up your cards." Large projects, especially if they require significant investments (in Chechnya \$5,000 is alread y a big sum) may attract a lot of unhealthy interest. People in official or unofficial power positions may try to control the projects or use them for their own benefit. Certain compromises on this are often inevitable, taking into account the complexity of the situation, but they should not become a serious burden to the project itself. One technique, that may be used sometimes (but not always) to overcome such obstacles is to allow an idea of something what would be good "in principle" to float around for some time in the selected community, thus forming a positive public opinion, before it is formulated into a concrete proposal. This is easiest to achieve when already cooperating with a local NGO or activist. Remember however, that there is no one set of universal guidelines, and what is right for one project and one location may be absolutely counterproductive in another case.

As it was already mentioned, suspicion of anyone from the outside is always very high in a conflict zone. Chechnyahowever, seems to beat all the records in this sense, with a very strong and broad "spy-mania." (For example: during the warif you happened to hang around a certain location not long before itwas bombed or shelled-you had all the chances to be considered a "fire corrector.")

It is typical for any foreigner to hear remarks every now and then about possibly working for some secret service, as well as "jokes" on that issue, etc. In itself this is normal and though may be quite irritating, there is no reason to panic. But it is important to behave as wisely and as carefully as possible trying to give no reason for any serious suspicions. Also, when the hostilities are carried out against journalists, humanitarian workers, human rights activists Chechens often later try to justify them claiming tha the victims were spies, etc. Try to avoid asking questions that are not directly related to your concerns.

And generally, be careful on your travels, avoid travelling at night. Stay in your friends' homes and try not to be alone for long especially when you are travelling. And if you do-it might be safer taking a bus than hiring a car. Russian proverb says, "God looks out for the carefuL"

\section{Ingushetia}

\section{General Information}

Unlike Chechnya, the small Ingush Republic is an example of significant progress achieved against serious obstacles. The Ingush Republic was established in 1992 in the territory of 4 districts of the former Chechen- Ingush autonomous Republic. The Ingush population voted overwhelmingly that year for remaining as part of the Russian Federation what was largely due to the fact that the Russian Parliament adopted a law "On rehabilitation of deported peoples, which included a promise of territorial rehabilitation."

As already mentioned the Ingush that were deported together with the Chechens to Siberia, Kazakhstan and Central Asia have lost the Prigorodny (Suburban) district, that was part of the Ingush Republic before the deportation. After their return in 1956, that district remained part of North Ossetia whose leadership was creating difficulties for the returning Ingush. In October of 1992 
a volunteer conflict erupted leaving around 700 dead and creating 70,000 refuges, most of them Ingush people from the Prigorodny district. So far less than half of those were able to return. Ingushetia also suffered greatly from the Chechen war right on its eastern border. At times it received over 160,000 refugees from Chechnya. In fact some of the first victims of the war were a few Ingushmen that protested as the federal troops were moving towards Chechnya through Ingushetia.

Yet, despite all these hardships, the Ingush Republic may serve as a positive example of progress achieved against great odds. The leadership of the Republic, headed by a former Soviet Army General Ruslan Aushev was able to negotiate with the federal government a set of economic conditions. Under them most Ingush businesses are practically tax-exempt. More than that, many Russian businesses were registered in Ingushetia for a small fee, which allowed them to drastically reduce their taxes. As a result, at a time when in nearly all regions of Russia the economy was declining, Ingushetia developed at a fairly high pace. Someone who could' observe the extremely poor situation in the Republic just a few years ago would be pleasantly surprised with all the new construction that has been and is going on today.

Another factor that contributed to the significant progress, achieved by Ingushetia is the success of the Ingush leadership in attracting significant international aid. Indirectly, during the last years, this was also a result of the poor security situation in neighbouring Chechnya, what caused many international organizations attracted by the Chechen crisis to operate in and from Ingushetia. The Ingush Republic did not only receive aid and assistance from various international organization and agencies for its own purposes, but became a major point of support for Chechnya, especially for the Chechens who became refugees in the territory of Ingushetia.

However, all this must not overshadow the fact that Ingushetia is still a tiny republic with a weak economy and

Refuge, Vol. 17, No.2 (April 1998) a huge amount of refugees, caught between to conflicts.

As already mentioned, one of the effects that conflicts and crises have is thai they encourage people to take their wellbeing into their own hands, thus increasing the civil activities of the population. This clearly has been the case in Ingushetia.

Despite the small population of the Republic, there were many more working NGOs created "per capita" in Ingushetia, than in other "quiet" regions. ${ }^{20}$ Obviously the most important problem that these groups had to deal with was the well-being of tens of thousands of refugees from the Prigorodny region, and over a hundred thousand refugees from the Chechen war.

\section{Nongovernmental Organizations of the Ingush Republic}

\section{Ingush Red Crescent Society}

Headed by Liza Amarhadjieva. Address: Recently Red Crescent Society moved to another address and since they still have no telephone connection installed, we cannot obtain the information about their address. We recommend getting the address from the International Red Cross office.

\section{Infonnation}

The Ingush Red Crescent Society is a unique organization compared with other NGOs by the scale of its operations and the number of people it was able to assis t. It was set up in 1992, soon after the tragic Ossetian-Ingush conflict. Since then it was able to help directly a few hundred thousand people most of themmany times. ${ }^{21}$ In addition to this, the Ingush Red Crescent Society assisted the operations carried out by other organizations and relief agencies. All this aid was directed to help refugees-both from the Prigorodny district of North Ossetia and from Chechnya. The society also helped organize medical centres at locations along the Chechen border when the fighting in the border areas intensified and just recently the Red Crescent Society began a program to help the" so- dally unprotected" people from

Ingushetia itself.

The Red Crescent Society has nine permanent and thirty-five part-time employees. Most of the part-time employees are representatives of the organization in various locations responsible for preparing lists of the families and people who are in greatest need and for organizing the distribution of aid to them.

The organization keeps track of all recipients and has a computerized database where it collects information. This information includes the number of people in the family that is receiving aid, the number of children, the group the recipients belong to (widows, orphans, disabled, single over the age of 65 and others) the area the family originated from, its present address, etc.

Recently the Red Crescent Society began to implement a program of aid for elderly people at home. The society is also prepared to organize urgent response to new crisis situations like the one that developed during the fighting in Grozny in August 1996.

\section{Needs and Perspectives}

The IngushRed Crescent society is probably the best organization to channel direct humanitarian aid to the population. It also has huge experience cooperating with various international organizations and relief agencies (ICRC,Oxfam, World Vision, etc.).

Whatthe society needs for its further development is the capabilities and the skills to communicate directly with various potential donors. For this the best thing would be to use email, but there are no email servers in Ingushetia. The main problem is ensuring a good telephone connection with some service that provides access to the Internet. Right now the possibility to do this is being discussed. Installing a cellular phone at this moment seems to be the cheapest solution to this problem. It will require around \$12-15,000. This email service, ifit is set up, could also be accessible for other NGOs in Ingushetia. The society also needs finances to extend its storage facilities and to increase the 
salaries for the part time staff in various locations.

\section{Committee of Ingush Women " Almos"}

Headed by Leila Muratovna Tsoroeva. Address: Ingush Republic, 366720 Nazran, Kartaeva Street, tel.: (81) 23716,242-02.

\section{Infonnation}

The Committee of Ingush women was registered on the 2 of March 1993, soon after the first presidential elections in the newly created Ingush Republic. The main objective of the organization is human rights protection. The Committee is involved in the following activities:

- Protecting the rights of Ingush soldiers, drafted to the Russian Army.

- Helping in the search for Russian military servicemen "lost" in the course of the Chechen war.

- Advocating on behalf of Ingush people who have been detained or broughtto court in the neighbouring regions (mainly in the territory of the Krasnodar and Stavropol regions).

- Maintaining an archive of materials (information, photos, etc.) of people who have been killed or "missing" after. the tragic events in the Prigorodny district in 1992.

- Lobbying in front of authorities on behalf of the" socially unprotected" people (single mothers, elderly people, widows, etc.). The committee helps such people to prepare various requests, appeals and other documents and to bring them to the attention of the official authorities. There are five people working in the

organization on a volunteer basis. Many others also participate in the activities of the Committee. For example: some lawyers, like the chairman of the Ingush Lawyers Committee Tamara Hautieva, together with women's "support groups" travel to other regions to participate in trials, where Ingush are involved.

After the beginning of the Chechen war, the Committee began to actively cooperate with Soldier's Mother's Committees all around Russia. The Ingush women's committee helps them find their children in Chechnya, bring them out-including cases when soldiers were taken as prisoners by the Chechen fighters. At the same time Soldiers Mothers Committees around Russia help in monitoring the conditions of Ingush soldiers in different Russian military locations and in defending their rights.

The Committee has participated in many antiwar activities since the beginning of the Chechen conflict. In June 1996, it has organized women to meet with the Russian and the Chechen delegations during negotiations in Nazran and hand over to them a petition with some specific proposals on how to stop the war.

The organization does not have a permanent office and is often forced to move. Nor does it have any serious financial backing.

\section{Needs and Perspectives}

The Women's Committee of Ingushetia over the past years has proved its effectiveness in many areas of human rights protection. At this point it needs at least some financial backing to be able to continue and expand its operations. It is most important to solve the problem of getting a permanent office and the necessary equipment for it. The second problem to work on is establishing communications. Third-to get a car in order to be able to work more effectively both in Ingushetia and Chechnya. And last but not least-at least some of the people working in the organization need to receive some salary, because there is a limit to how long people can work as volunteer.

In order to achieve all these objectives members of the Women's Committee of Ingushetia need some assistance and training in writing proposals, using computers and other skills that are important for their work,22 In solving the task of developing and maintaining communications it would be bestto cooperate with other Ingush NGOs, including the Red Crescent Society.

\section{Council of Social Organizations of the Ingush Republic}

Headed by Chairman, R. Buzurtanov; coordinator L. Tsoroeva.
Address: Ingush Republic, $366720 \mathrm{~N}$ azran, Chechen Street 5, fax: 9234066 (Moscow number in Ingushetia).

\section{Infonnation}

The Council of Social Organizations of the Ingush Republic was organized in February 1995 with the purpose of developing communication and coordinating efforts between different Ingush NGOs. It consists of12 separate groups. Some others are considering the possibility of becoming its members.

Most of the work of the Council has been related to the tragic events in Chechnya and in the Prigorodny district of North Ossetia. It lobbied on behalf of the forced migrants from the Prigorodny Region, organized and participated in many actions opposing the war in Chechnya, participated in the negotiation process on different levels between North Ossetia and Ingushetia, took part in various press conferences, etc.

Recently it prepared and sent a grant application to the Open Society Institute requesting $\$ 10,000$ for a program aimed to help legal education in Ingushetia, monitoring the human rights situation in relation to refugees and publishing a newsletter.

\section{Perspectives}

The task of uniting efforts of various NGOs is certainly very important and must be encouraged. Also, the Council of Social Organizations of the Ingush Republic seems to be a good organization to focus on solving the communications problem for Ingush NGOs. Perhaps it could unite its efforts on this issue with the Red Crescent society. It is also an organization that may assist NGOs and organizations from other regions and countries in finding partners for their programs in the Ingush Republic.

\section{List ofNGOs,Members of the Council of Social Organizations of the IngushRepublic}

Women's Committee of Ingushetia "Almos"

Union of Veterans of World WarII

Refuge, Vol. 17, No.2 (April 1998) 
Union of V eterans of Afghanistan of the Ingush Republic

Chernobyl Union of the Ingush Republic

Union of Cossack Formations of the Ingush Republic

Union of the Deported from North Ossetia

Charitable Fund for Social Protection of Motherhood and Childhood Committee

for the Search for Hostages and "Missing"

Actors Union of the Ingush Republic Artists Union of the Ingush Republic Federation of Child and Teenager organizations of the Ingush Republic Youth Ecological Organization "ECOS"

A new organization that is not located in Ingushetia but whose operations are mostly focused on the Ingush Republic is:

\section{Association for the Protection of Deported Peoples}

Address: Moscow at 129110 Moscow, Gilyarovskogo Street 39, office 800, tel. /

fax: (095)

971-28-27,

email: isp@jnvluk.msk.ru

\section{Infonnation}

It plans to be an all-Russian organizationbut so far most of its activities were related to Ingushetia. Unlike other NGOs this is a wealthy organization (its Chairman, Muharbek Aushev, is one of the directors of the largest Russian oil company). Its declared goals are:

- networking between various deported peoples support organizations;

- developing a complex Program for the liquidation of the consequences which result from interethnic conflicts, based upon the experience of the Ingush-Ossetian conflict;

- organizing and participating in conferences and seminars, related to the problem of deported peoples protection;

- developing projects, which will help to create new jobs in the Ingush Republic;

Refuge, Vol. 17, No.2 (April 1998)
- assisting in solving the housing problem for refugees and displaced persons; and

- rehabilitation programs for children who suffered during the Chechen war.

This organization has already delivered humanitarian help and equipment to hospitals, orphanages and the IngushState University. The organization itself and its activities seem to be interesting, but so far we have not had any working experience with them.

\section{Dagestan}

\section{General Information}

The republic Dagestan is a subject of the Russian Federation, it consists of 42 administrative districts. $^{23}$ Its capital is Mahachkala. On the south, Dagestan borders with Azerbaijan, on the southwest with Georgia, on the west with Chechnya, on the northwest with the Stavropol Region, on the north with Kalmykia. The southern part of the Republic is covered with the foothills and the mountains of the Main Caucasus Range, and on the east it stretches along the Caspian sea.

In the yea,r 1813, according to the Gylistan treaty the territory of modem Dagestan was attached to Russia. In 1817, the mountain peoples of Dagestan began an anticolonial campaign referred to as the Caucasian war. It lasted till 1864, when it was finally suppressed by the Russian Empire. On January 20, 1921 after a two-year war with German and Turkish forces and the "White Guard" the Dagestan Autonomous Republic was formed as part of the Russian Soviet Socialist Republic (RSFSR).

According to the census of 1989, the population of Dagestan amounted to 1,802,188 people. According to the data in 1995 the population increased to 2,066,657 among which there were representatives of 102 nationalities. The largest ethnic groups were the Avar, Agul, Azerbaijan, Armenian, Chechen,24 Dargin, Kumyk, Lak, Lezgin, Nogai, Russian, Rutul, Tabasaran, Tatar, Tsahur, Ukrainian.
The languages of the various ethnic groups in Dagestan belong to three linguistic groups: the Turkish, the IndoEuropean, and the Iber-Caucasian language groups.

From the beginning of perestroika in the former USSR, many problems surfaced and began to grow rapidly, relating to national questions, divisions based on ethnic backgrounds and interethnic relations. In Dagestan, where there is such a variety of ethnic groups, interethnic tensions and contradictions developed. However, these problems did not lead to the volunteer conflicts that took place in many other regions. In Dagestan the increase in interethnic tensions was limited to the development of different national movements, various demonstrations and a few separate incidents that did not develop into a serious conflict. But there are many cases when people who found themselves in a relatively more vulnerable position suffered from criminal activity, while authorities were unable, or too passive to protect them and the general public remained indifferent to their problems.

During the past several years, Dagestan was in a situation close to an economic blockade-the only railroad connecting the Republic with Russia goes through Chechnya and could not operate because of the events there. The border with Azerbaijan was closed. Dagestan is in the middle of a severe economic crisis and crime in the Republic has increased sharply (even more so then generally in Russia). All this, together with the growth of ethnic tensions, leads to a strong outflow from Dagestan of mainly the Russian and the so-called "Russianspeaking" population. At the same time a difficult economic and political situation in Russia and other NIS countries has resulted in even greater return flow of ethnic Dagestanis from other regions and countries.

The armed conflict in Chechnya and the huge flow of refugees also had a negative impact on the situation in Dagestan. 


\section{nic Tensions and \\ Contradictions in Dagestan}

The ethnic diversity of Dagestan, the interconnection of cultures of the various peoples, living side by side for many centuries developed certain norms of behaviour. These norms helped avoid any major armed conflicts in Dagestan despite the fact that tensions often ran very high and serious contradictions still exist. It is possible to indicate the following most important areas of tension:

- The Novolak(former Auhovski) district-relations between the akkinChechens and the Lak (problems of resettlement of the formerly deported peoples).

- Tensions and problems along the Dagestani-Chechen border.

- Area populated by the Lezgin, divided by the Russian-Azerbaijani border.

- Problems of the Nogai people, divided between Dagestan, Chechnya and the Stavropol region.

- Similar problems of the Terek Cossack's, divided between Stavropol region, Chechnya and Dagestan. ${ }^{25}$

We shall take a look at three of these situations that we consider most important. We believe thatthe situations that developed in the Novolak district and along the border with Chechnya are the most urgent and explosive, and potentiallymay develop into open interethnic conflicts so they deserve immediate attention. The situation on the border with Azerbaijan still remains quite tense, but seems to have improved over the past years and is less likely to lead to serious problems (which does not mean that it does not deserve attention).

\section{Novolak (Auhovski) District:}

\section{Contradictions between the} Lak and Akkin-Chechens

There was no Novolak district before 1944, its territory belonged to the Hasavyurt area. In 1943, part ofthe territory of the Hasavyurt area was designated as the Auhovski district, populated mainly by the akkinChechens.
In February 1944, after the deportation of all the Chechens, the Auhovski district was abolished. Instead of it the Novolak district was formed where in March of 1944, 1,300 Lak families wore moved from the Lak and Kulin districts of Dagestan.

In the process of resettling the Lak people, twenty-four villages, 1,300 families were moved to nine villages in the newly created Novolakdistrict. People were given one wagon for three families. On the road some people died from the cold weather and malnutrition. When they came they were put in the houses left by the akkin-Chechens. Many people died during the first three years after the resettlement. 26

In the process of deportation the property of the akkin-Chechens was left behind. All they were allowed to take were some clothes and a small amount of food. Cattle, property. houses-all of that was left behind. A large percent of the deported died in the first few years after deportation.

In 1957, after the deported peoples were allowed to return to their homelands, the akkin-Chechens returned but they were not permitted to go back to the $\mathrm{N}$ ovolak district, formed in the place of the Auhovski district. Instead they were given about 20,000 hectares (almost 50,000 acres) of land in the nearby Hasavyurt district.

Since 1957, there were some rather serious collisions between the akkinChechens and the Laks and in 1991-93 contradictions between them have increased. The akkin-Chechens wanted to return to the homes of their ancestors. The Laks were not against this in principle, but they demanded that the government of Dagestan should first allocate territory and finance the construction of nine towns and villages for the Laks to move to.

On the third congress of the national deputies of Dagestan in 1991, a decision was made to create an organizing committee for the restoration of the Auhovski district and an organizing committee for the resettlement of the Lak population of the $\mathrm{N}$ ovolak district.

A governmental program was accepted: a territory of 8,500 hectares
(21,000 acres) in the Kumtorkalinski district near Mahachkala was allocated for the new Lak towns and villages to be built and 3,150 Lak families were supposed to move there. The resettlement program for the Lak people should have been completed in 1996, but due to shortages in financing only around 20 percent of the resettlement program has been accomplished so far. Since the Laks cannot move from the $\mathrm{N}$ ovolak district this means that the program ofrestoring the Auhovski district cannot be implemented. The akkin-Chechens propose to restore the Auhovski district before the Laks move out. But the Lak demand that the process of restoring the Auhovski district and the resettlement of the Laks should happen at the same time.

Tension grows, the akkin-Chechens take over lands, demand that their ancestor's houses be freed, that all the paragraphs of the law "On Rehabilitation of Deported Peoples" be fulfilled. The Laks resist the pressure from the akkinChechens, organize demonstrations and try to pressure the government of Dages tan.

Due to the lack of financial resources, the Russian government made a decision to change the deadline for the implementation of the resettlement program for the Lak population of the $\mathrm{N}$ ovolak district and for the restoration of the Auhovski district till the year 2000. Thus, the work that needs to be done in order to solve the problem has nearly been brought to a halt. There are objective reasons for that, but the further the resettlement program will be delayed, the higher interethnic tensions will rise between these two peoples.

\section{Problems and Growth of \\ Tensions along the Chechen- Dagestan Border ${ }^{7}$}

Most of the people in Dagestan felt compassion toward the Chechen people during the war in Chechnya. Many considered this war to be a national liberationmovement of the Chechen people ${ }^{28}$ From the first days of the war the Dagestan population actively participated in an antiwar movement,29 people demonstrated, blocked roads and

Refuge, Vol. 17, No.2 (April 1998) 
did not allow the federal troops to enter Chechnya from Dagestan.

The government and people of Dagestan did what they could to assist refugees from Chechnya. Nevertheless on January 9,1996 the Dagestan city of Kizlyar became the object of a raid that must be qualified as a terrorist attack by a few hundred Chechen fighters, led by Salman Raduev. ${ }^{30}$

Early in the morning the Chechen fighters entered the city and terrorised it. They took over the city hospital with its patients and a maternity house next to it. They drove people from their homes and apartments and gathered a total of over 3,000 hostages. As a result there was the most powerful explosion of anti-Chechen feelings in Dagestan. There was a high probability of actions against the Chechens living in Dagestan as well as against the refugees from Chechnya. The interference of the Dagestan leadership made it possible to avoid a military solution in the city of Kizlyar. The fighters released most of the hostages, and about 150 of them, including members of the Dagestan leadership, agreed to leave Dagestan peacefully in a convoy of buses. But on the very border between Dagestan and Chechnya near the village of Pervomaiskoe, the convoy was stopped and surrounded by federal troops. Attempts by the Dagestan leadership to secure a peaceful solution to the crises were ignored and the Federal government took over the operation. Meanwhile the fighters took up defence positions in the village. The Federal ministry of Interior and the Federal Security Service, headed personally by ministers Kulikov and Barsukov organized an armed operation of "eliminating terrorists and freeing the hostages" that began on 15 January. The operation that was planned to be a few hours long took four days. Both sides suffered heavy losses and quite a few of the hostages were killed in it. The village was completely destroyed. On the night of January 18th, Salman Raduev was able to break through the Federal lines and with a group of fighters and hostages (who were later released) disappeared in the territory of Chechnya.

Refuge, Vol. 17, No.2 (April 1998)
Events in Kizlyar and Pervomaiskoe have once again exposed the inability of the leadership of Russia to take care of crises, its poor understanding of the real situation on the ground and the rigid and unprofessional style of its operations. In Dagestan many people got the impression that the real intent of the Russian government was to pull Dagestan into an open military confrontation with Chechnya. The operation carried out in Pervomaiskoe was so obviously worthless and senseless that after the anti-Chechen attitudes among the population of Dagestan have begun to diminish at the expense of a growing discontent over the actions of the Federal authorities of the Russian Federation.

The Kizlyar tragedy united all the ethnic groups of Dagestan, and weakened the contradictions between them. At the same time, itlead to an increase in antiChechen feelings among the Dagestan population. These antiChechen feelings spread to the akkinChechens who live in Dagestan. Many people see the akkinChechens as proponents of Chechen separatism.

Gradually anti-Chechen feelings began to diminish but after the signing of the peace agreements in Hasavyurt on August 26,1996, when military activities in Chechnya ended and were replaced by a fragile peace, when one should expect the situation to stabilise, anti-Chechen feelings again began to grow. Raids constantly take place from the Chechen territory onto the neighbouring Dagestan districts during which cattle and cars get stolen, robberies take place, and sometimes hostages are taken in order to extort money and so on. The representatives of allnationalities of Dagestan suffer from these criminal activities.

Another cause of tensions are the statements of various Chechen leaders that the Hasavyurt and the Novolak (Auhovski) districts are ancient Chechen territory. 31

There is an opinion among the Dagestan peoples, that if the program for restoration of the Auhovski district will be implemented (today the Chechens demand the return of this dis- trict and also want to maintain their lands in the Hasavyurt district)32 these districts will de facto become a part of Chechnya, even if they formally remain part of Dagestan.

Such fears, fuelled by certain statements by Chechen leaders and constant provocations on the border, lead to the growth of anti-Chechen feelings in Dagestan. Demands were already made to create self-defence units in all regions of Dagestan bordering with Chechnya, to permit the carrying weapons, to conduct a strict account of all Chechens, living in Dagestan, including refugees from the war.

The akkin-Chechens themselves often state that in their culture, traditions, and way of life they are closer to the peoples of Dagestan than to Chechens living in Chechnya. ${ }^{33}$ During the tragic events in Kizlyar and Pervomaiskoe the Dagestan Chechens actively participated in the search for a peaceful solution, negotiated with Salman Raduev compelling him to give up one position after another. During hostilities in Chechnya the leadership of the separatists hoped that the akkinChechens would support their armed struggle, but this has not taken place. Dagestan Chechens condemn provocations and robbery on the border, they understand that as soon as the patience of the Dagestan people breaks the first reaction will be against them. However nowadays, in the euphoria of their victory, many Chechens tend to identify themselves with Chechnya more than before. In general the akkinChechens are in a contradictory situation. On one hand they are Chechens, they have strong ties with Chechnya and are influenced from there. On the other hand they are residents of Dagestan and are under pressure from the Republican leadership and population. The leaders of the akkin-Chechens repeatedly stated their clear position that they are inhabitants of Dagestan and like all Dagestan are oriented to remain within the Russian Federation.

The leadership of Dagestan and its population are obviously satisfied with the end of the war in the neighbouring republic but in reality the long awaited 
peace brought an aggravation of the situation on the Chechen-Dagestan border.

\section{Area of Residence of the Lezgin, Divided by the Russian- Azerbaijani Border}

After the disintegration of the Soviet Union the Lezgin found themselves divided by the Russian-Azerbaijani border. Similar situations developed in many areas within the post-Soviet territory: Ossetians in Russia and Georgia, Russians in Ukraine, Estonia and Kazakhstan, Armenians in Azerbaijan, Azerbaijanis in Georgia and so on. In some regions the growth of interethnic tensions lead to an open armed conflict between the ethnic minorities that refused to accept the new arrangements and the titular national groups. Contradictions between the Azerbaijanis and the Lezgin were high and some volunteer incidents took place over recent years on both sides of the border, although a large volunteer conflict did not develop. One of the major reasons for tensions was that the border between Russia and Azerbaijan was closed and relatives from both sides faced difficulties in crossing it.

In the beginning of September 1996, there was a decision made by the Russian government to ease the procedure for crossing the border. Air, railway and bus communications were opened between Dagestan and Azerbaijan. The border is completely open for the women and children as long as they can present their ID (a passport or birth certificate). Young men of "drafting" age need to present on the border a passport with their residence permit (propiska)34 or a special permission document that can be easily obtained in Mahachkala.

There is a certain contradiction. For example if a representative of our organization Nonviolence InternationalNIS departs from Moscow to Azerbaijan he does not need to receive any special permitting documents, all he needs is his regular internal passport. If he will go to Azerbaijan from Dagestan, it will be necessary for him to receive for this a permission paper in Mahachkala. This is clearly a double standard in the legislation.

\section{Situation of Refugees from Chechnya}

During the war in Chechnya, Dagestan received around 150,000 refugees. Taking into account, that the economic situation in Dagestan is very difficult, accepting such numbers of refugees has created additional problems due to the need to finance their housing, livelihood,etc.

The flows of refugees changed depending on the intensity of the fighting inChechnyaand the geography ofmilitary actions. When fighting intensified in one or another Chechen location the number of refugees increased and as soon as the fighting ceased many refugees went back to their homes. Many refugees did not register, especially during the first months because during the registration a form (113) was filled out which was similar to the form that was filled out during the deportation in 1944 and people were afraid of possible consequences of their registration. ${ }^{35}$ Many refugees did not have documents. They were registered without them and in such situations employees of registration centres had the opportunity to abuse their power during the distribution of humanitarian aid. Nor are such abuses excluded on the part of the refu-gees themselves, when they could register at different locations under different surnames. Many refugees went to their relatives or friends. Besides, many residents of Dagestan have left for other regions of Russia and countries of the NIS to their relatives, parents, and children. As a result of all this, there is no clear statistic of refugees and in the district branches of the Committee on Labour and Employment there are data only about those refugees, who were actually registered.

Most of the refugees coming to Dagestan from Chechnya during the entire period of the war stayed in the city of Hasavyurt and the Hasavyurt district. The maximum number of refugees that came to the city was almost 65,000 and to the district-about 60,000 per- sons. In O<:tober 1996, there were around eight thousand left in the city and seven thousand in the district. In the Novolak district, that received a total of about14,000 people, 116 refugees were left. The Kizlyar district accepted 7,560 people and the Tarumovski district received almost fifteen hundred, of whom a nearly a thousand returned to Chechnya.

Most of the refugees stayed in the private sector. Local people felt compassion and did what they could to help. Besides that, the administration of the bordering districts found buildings for the refugees to use (schools, nurseries, educational and industrial facilities, etc.) The refugees received 2,465 rubles a day and the people or organizations that provided housing received 1,000 rubles a day.36 But even this minimal support did not last very long, somewhere around October 1995, this financing stopped.

In this situation an important role was played by international organizations, which rendered medical services, brought and distributed medicines, food, clothes and so on. The Dagestan Ministry on Emergency situations, the Federal Migration Service have also worked actively.

At the present moment many managers of buildings, where the refugees live, want them to return to Chechnya as soon as possible. This occurs because electric power and gas are used and the costs of these services are not compensated. The refugees themselves, knowing the economic situation in Dagestan, feel uncomfortable and understand that they are a burden. But many people re. ally have nowhere to go. When the administration of the Hasavyurt district gave the lists of refugees to the administrations of the Chechen city of Gudermes, the Nogaiyurt, Vedeno and Shali districts of Chechnya it discovered that around 70 percent of these refugees live at home in Chechnya. So there are many cases when a person lives in Chechnya at home, but receives humanitarian aid as a refugee in Dagestan.

We believe that it is important to assist the return of refugees, whose homes

Refuge, Vol. 17, No.2 (April 1998) 
remained, who have the finances and opportunities to live in Chechnya. This will decrease the number of refugees in Dagestan and it will become easier to help those who are in the most desperate situation, who lost their houses, don't have enough means for livelihood etc. For: this purpose it is necessary to transfer activity of international organizations from Dagestan to Chechnya. Taking into account the risks and the difficulties of that and the reaction of international organizations to the killing of the six ICRC employees, it is possible to use potential local activists, NGOs and people who helped the operations of international organizations in Chechnya.

\section{Migration of the Population and \\ Its Reasons}

For many decades, during existence of the USSR, migration flows were directed out of Dagestan. Since 1992, as a result of a new political situation, these flows have changed. The inflow of the population has exceeded the outflow. It is possible to follow the most important tendencies in the migration of the population in and out of Dagestan:

- Migration of the Russian and other "non Dagestanian" population from Dagestan.

- Migration of ethnic "Dagestanis" from the NIS countries and Russia into Dagestan:

\section{Migration of the Russian and Other "Non-Dagestani" Population from Dagestan Migration flows of the Russian and "Russian-speaking" population from Dagestan can be defined as:}

- From cities and districts, where the Russian population made up a minority of the population.

- From districts, where the Russian population was traditionally the majority.

The most important reason that causes the "Russian-speaking" population to migrate can be called "social vulnerability." This population as a rule is working in plants, factories, technological enterprises, etc. As a result of the economic crisis in the country these factories have stopped functioning. This effected the "Russian-speaking" population of Dagestan in particular. People were left without salaries and they did not have other sources of income. As the power of the federal and local government diminished and interethnic tensions increased, the Russians as the least protected found themselves under criminal pressure. ${ }^{37}$ Russians, who often worked as qualified specialists in different enterprises were provided apartments during Soviet times. Criminal structures would take away people's apartments or force them to sell their flats for low prices. Through fraud, criminals received documents allowing them to take them over. There were some cases, when the owners of apartments were killed, or kidnapped in the process of taking their apartments over. Republican authorities did, to a certain extent, try to protect the Russian population but in a situation when the leadership itself is in crisis, the Russian and "Russianspeaking" population remains under the pressure of criminal structures in those towns and villages where it is a minority.

Another factor that forces the Russian and "Russian-speaking" population to leave is the consequences of the migration of the Dagestan peoples from the mountain areas of the Republic onto the plain. This process began in the 1970 s, and was connected to the fact thatlifein the mountains had poor perspectives-there was a shortage ofland, farms were unprofitable, there were no jobs, etc. On the plains ${ }^{38}$ there was a shortage of labour, industrial production and cattle farming were expanding and so on.

In the Tarumovski district there was no organized migration from the mountains. Ethnic "Dagestanis" came on their own personal initiative and this was welcomed. In the Kizlyar district there was organized migration from the mountains, people were given land, whole new villages were built for the migrants, they were provided building materials, given jobs and so on. This, at the time, did not create ethnic conflict.
But because of the "tuhumstvo," the strong family ties, once a person moved to the plains and settled there, he would try to bring his parents, brothers and other relatives. At the same time the Russian youth, after competing higher education, tried to find jobs in other areas of the country. This mainly happened because for them the chances of making a successful career in Dagestan were very small. Because all that, the birth rates and the population growth of ethnic "Dagestanis" was much higher than of the Russian population.

So by the middle of the 1980 s, the percent of Russian and "Russianspeaking" population in the republic has sharply decreased, even In those districts where they made up a majority. With the beginning of "perestroika" ethnic tensions grew, people began to divide themselves based on their ethnic background and the further this process continued, the more complicated things became. Under these conditions the migration of Russians out of Dagestan increased significantly.

When the war began in Chechnya and especially after the tragic events in Kizlyar, fear of these events spilling over the border into Dagestan spread among the "Russian-speaking" population, especially in the areas near the Chechen border.

During the last few years, the reasons for migration are related to the war in Chechnya, to some statements of various Chechen leaders about the need to unite the Hasavyurt and Novolak (Auhovski) district with Chechnya, to tensions along the border, constant provocations, stealing cattle, taking hostages etc ..

It is possible to designate the following reasons for the migration of the Russian and "Russian-speaking" population from Dagestan:

1. Poor economic conditions. ${ }^{39}$

2. Social vulnerability of the "Russianspeaking" population, especially in the cities and districts, where it is a small minority.

3. Fear related to the Chechen war and problems on the Dagestan-Chechen border. 


\section{Migration of Ethnic "Dagestanis" from NIS Countries and Russia back to Dagestan}

At the time of the Soviet Union people left for the regions of Russia and the Union Republics to work, to receive and continue their education, make a career and so on. As a result of the collapse of the USSR, political and economic hardships in the NIS, growth of interethnic tension and sometimes even open persecution, the migration flow of ethnic "Dagestanis" has reversed and people have begun to return to Dagestan.

The return of "Dagestanis" from Central Asia, Azerbaijan, Georgia, Russia takes place for the following main reasons:

- a very low living standard in Central Asia;

- a very low living standard and ethnic tension in Azerbaijan and Georgia; and

- pressure and abuse of power on behalf of local authorities against all native peoples of the North Caucasus and the Trans-Caucasus including the ethnic "Dagestanis."

As it is nearly impossible to live in the mountains, all returning people try to settle in the plains. People from the mountains also try to move to the plains which creates internal migration (people depart from their homes because there is no work).

There are almost only old people left in the mountains today who live on their pensions and large families that receive child support. As it was mentioned above there is a very complicated economic situation in Dagestan. People returning to the Republic and those who have migrated from the mountains try to find jobs, but everything is occupied as there is a huge deficit of jobs. That's why many people are forced to earn a living by criminal or semi-criminal acts. Tension and ethnic contradictions are rising in the Republic.

One of the most difficult situations in the context of the return of ethnic "Dagestanis" is the immigration to Dagestan of the $\mathrm{K}$ varely A vars from the $\mathrm{K}$ varelski district in Georgia. "K varely"
Avars have lived in the Kvarelski district of the Georgian Republic for over a cenhiry. They were located in three villages- Tivi, Sarusu and Chindijskuri. When Zviad Gamsahurdia came to power in Georgia they found themselves under pressure.

The roads to their villages were blocked, people stopped receiving pensions and benefits, the vineyards were confiscated, and there were threats of physical massacre. The "Kvarely" A vars have requested the leadership of Dagestan to help them move back to their historic motherland.

"K varely" A vars were offered to migrate from Georgia to the city ofYuzhnoSuhokumsk in the Nogai district of Dagestan. The steppe covers most of this district, there is a shortage of water, that's why most of the migrants do not want to move there.

Nevertheless seven buildings have been constructed in this city for the migrants to live in, but most of the migrants moved to Mahachkala, to the Stalskoe village of the Kizilyurt district and to the Kizlyar district, which are all in the plains.

Two-hundred-thirty-five families moved to Dagestan and 705 families stayed in Georgia. All migrants, both those who already moved and those who were in Georgia received pensions, benefits and medical assistance in Dagestan as they could receive it in Georgia.

This process has already lasted over five years. The time frame, which had been set by Federal institutions and the government of Dagestan came to an end, but the plans were not realized. The government of the Russian Federation does not provide sources of financing to fulfil the program of migration (except for the Federal Migration Service of Russia, which provided financing for buying and assembling buildings for the migrants from Georgia). The leadership of Georgia declares that it cannot pay compensation for the property left behind by the migrants (houses, gardens etc.) because it does not have the money. As a result, people are in a complicated situation, neither in Georgia nor in their historical homeland are they needed and they do not trust any governments.

\section{Nongovernmental Organizations and Activists of Dagestan}

In the process of their work in the territory of Dages tan, the members of /IN onviolence International" Society have contacted a few NGOs and an expert of the Network for Ethnological Monitoring.

\section{Charitab Ie Fund "Medik" (KizIyar branch)}

Registered in May of 1993. Operates in Kizlyar.

Headed by Andrey Tretyakov. Address: Dagestan Republic, Kizlyar, Pobedy street 1, apt. 2., tel. in Kizlyar: 230-98. ${ }^{40}$

\section{Information}

The main activity of the Fund is to render medical and social help to children, disabled, elderly, war veterans. Initially the Fund rendered assistance to people at their homes-people with low incomes, with health problems when they could not come themselves to the medical facilities.

The Fund rendered social help. It took patronage over children's institutions in town and over a special school in Mahachkala. This activity was supported by the students of Dagestan Medical Institute and did not last long because its financing was terminated.

After the tragic events in Kizlyar, the Fund assisted medical and children's institutions of the city in receiving medical supplies, children's toys and distributed warm clothes in the village of Pervomaiskoe.

\section{Perspectives}

At the present time the Fund, incooperation with Nonviolence InternationalNIS is developing a project aimed to organize psychological assistance for the children, doctors, teachers who suffered from psychological stress during the tragic events of January 1996. This is planned as a fairly inexpensive project (around $\$ 7,000-8,000$ ) and could serve as a pilot project for similar programs in

Refuge, Vol. 17, No.2 (Apri11998) 
other areas that suffered from the war, including Chechnya itself.

Hasavyurt Regional Charity Fund

"Spasenie" ("Salvation")

Contacts: The Chairman of the Fund Umar Djavtaev, Chairman assistant Vahmurad Ashabov and Irainat Karimova.

Address: Dagestan Republic, 368005 Hasavyurt, Zarechnaja Street 63, tel.: (8722310) 36-64.

\section{Infonnation}

The main direction of activities of the Fund is creation of an assistance centre for refugees from the Chechen war. This centre renders the following assistance:

- legal aid to the refugees;

- finding buildings for housing refugees;

- promoting the media to highlight the problems that concern the refugees;

- help in the search for Russian servicemen who were captured as prisoners of war; and

• searching for "missing" people.

\section{Perspectives}

As the war has been declared over and the majority of refugees have already returned to Chechnya, this organization can readjust to the new challenges it is facing and play an important role in easing tensions on the ChechenDagestan border. Nonviolence International-NIS hopes to assist this NGO as well as the one in Kizlyar in getting an email address.

\section{Kisriev Enver (an expert of the \\ Network of Ethnological Monitoring and Early Waming of conflicts)}

Address: Dagestan Republic, 367012 Mahachkala, Marksa Street 11 G, apt. 21, tel.: (22) 67-3974, (22) 67-2795, email: enver@eawam.dagestan.su

\section{Infonnation}

Enver Kisriev is a highly qualified specialist, an expert in the fields of ethnology, anthropology and interethnic relationships in Dagestan. He is a consultant at the People's Council-the highest governmental body in
Dagestan. Though he is not really an NGO activist, we believe it is right to include him in this publication because his expertise might be of great value to any organizations or agencies that decide to work in this troubled region.

\section{Gulnara Ahmedova}

Address: Dagestan Republic, Mahachkala, Marksa Streer 11 G, apt. 21, tel.: (22) 67-2795.

\section{Infonnation}

Gulnara is a young woman from Dagestan living in Mahachkala. She has attended some youth conferences with representatives of various NGOs from the Caucasus. At present she is not a member of any specific NGO, but is very interested in the possibility of getting involved in some organization where she could contribute to peace and interethnic cooperation in her Republic. She could be a useful person to contact in Mahachkala if her help is needed. I

\section{Notes}

1. This doesn't mean, however, that bloodshed has ceased completely.

2. It is natural that such divisions are rather conditional, especially between the second and third category. Some organizations, such as ICRC, 10M occupy a kind of intermediate position.

3. For example: $10 \mathrm{M}$ operations in Chechnya began, basically, through cooperation with a small Moscow-based NGO and some local Chechen activists, who on their own had already begun to evacuate civilians from Grozny in January 1995 at a time when the fighting in the city reached its peak and no official or international agency was able to operate in that area.

4. For example, during the work in Chechnya, the International Organization for Migration was often confused with the Russian Federal Migration Service what caused sometimes negative attitudes toward it.

5. Abstractly speaking, each era brings forward certain people. But when times begin to change at a kaleidoscopic pace many people appear who were pulled out of their everyday lives and become leaders in different spheres but after a short time the need for them in their new capacity vanishes.

This is seen best when you look at politics and note an unreasonably high number of various parties and movements built around different figures who claim to be serious leaders. However, a similar situation may be seen in the field of NGOs and among people whb worked for along time in different international organizations.

6. The given list by no means can be considered complete. We know that there are many more people and organizations who worked no less than the ones we mentioned and therefore we apologise for not including them in the list. However, it is nearly impossible to know and mention everybody.

7. Recently this organization published a small brochure with advice for NGO representatives who are planning to work in conflict zones. We highly recommend to look at it as well.

8. The Chechens often use the nickname "In_ dians" for such groups-nothing against native Americans, however.

9. Helping those in need is generally an important aspect of Muslim culture. We have observed in different conflict zones of the former USSR that countries and territories which are predominantly Muslim are more successful in dealing with such human consequences of crises and wars as huge refugee flows often with less available resources to begin with.

10. The local NGO responsible for this project is the Society for Peace and Human Rights. It is headed by Shaman Adaev, a young Chechen who became well-known for his work with journalists, human rights activists and with international organization throughout the entire war.

11. In fact, the word Sernovodsk comes from the Russian "Sernye vody," which means sulphur waters. Before The war there was a large sanatorium located in the village Unfortunately, it suffered the heaviest damage during the events of March 1996.

12. That does not mean that it is theoretically impossible to have a return on your investments, but that completely depends on the ability of your partner to make a profit in an extremely difficult environment and secondly-on his willingness to share the profits with you. No legal instruments are available today to guarantee any agreements and it is doubtful that they will appear in the foreseeable future.

13. For example, one of the large round central squares was given (unofficially) the name "Minutka" because once upon a time there was a cafe by that name next to the square. I remember how after a month in Grozny, I still had difficulties figuring out what people meant when they described their addresses in a manner like "the third house on the left when you turn right of the Minutkasquare." 
5)

14. One of the peculiarities of the situation with Sernovodsk and therefore with the society "For Peace and Human Rights" is that administratively Sernovodsk is in some cases still considered part of the Ingush Republic within the Russian Federation. The reason for thatis that when the former Chechen-Ingush Autonomous Republic split in 1992, there was a decision between the Chechen and the Ingush leadership notto draw a border line in order to avoid conflict. Sernovodsk used to be part of the Sunjenski district of the ChechenIngush Autonomous Republic, a district that was considered to become part of the new Ingush Republic. However, the majority of the population of the village are ethnic Chechens and de facto Sernovodsk became part of Chechnya. As it was mentioned, in March of 1996 the Russian mili tary surrounded, bombarded and "cleansed" the village, thus recognizing it as Chechen territory. At present the village has a Chechen leadership and there is no serious debate over its belonging to Chechnya. Yet in papers it is still often considered part of Ingushetia, so Shaman's society is registered as a public organization according to Russian law.

15. Articles about these visits and other activities in which the group participated have been published in the "Joint Nonviolent Action" newsletter, contact Nonviolence InternationalNIS.

16. For example, you may hear such remarks as "There's no God, there is Allah."

17. Today the number may have changed.

18. Right now, for example, just in order to hire a truck load from Grozny to Shali (about 30 miles) it is necessary to pay 350,000 rublesthat's enough for the survival of a family of 34 people for a month.

19. Members of Nonviolence InternationalNIS did not have an opportunity, so far, to meet Vaha themselves. The information published came from other Chechen NGOs that are known to be reliable.

20. However the small size and population of the Republic leads to the fact, that there are proportionately many more "government" jobs "per capita" then in other places. This creates opportunities for some potential activists to find themselves a role in government structures.

21. For a republic like Ingushetia the operations of the Red Crescent Society may be compared with the work of some government ministries and agencies.

22. Nonviolence International-NIS plans to help in this.

23. Districts and cities are considered separate administrative entities. The large number of fairly small districts in the republic is also related to the diverse and complicated ethnic composition of Dagestan.

24. The Chechens that live (or lived) in Dagestan are known as the akkinChechens.

25. The Cossacks demand the return to the Stavropol region lands along the north bank of the Terek river, that were attached to Chechnya in 1956.

26. This is an interesting fact. Recently there was a lot of information about the deported peoples and the terrible losses they suffered during the deportation. But the people that were relocated to the areas left by the deported peoples also suffered greatly. In some ways this "relocation" was similar to the deportations. The Stalinist totalitarian system was ruthless in everything it did.

27. Administrative districts of the Dagestan Republic that border on Chechnya are the Tsumandinski, Botlihski, Gumbetovski, Kazbekovski, Novolak, Hasavyurt, Babayurt, Kizlyar, Tarumovski and Nogai districts.

28. A recent survey showed that this was the opinion of more than 35 percent of the population of Dagestan.

29. Obviously, the most active antiwar movement developed in the areas bordering Chechnya where there is a large population of akkin-Chechens. In the first days of the war a number of federal armed personal carriers (" APC") with their crews were captured with the support of the local population in the territory of Dagestanand then transferred toChechnya.

30. The Chechen fighters claimed that initially there was no plan to attack the city and the objective of the operation was to destroy a helicopter airfield located next to the city, that was used as a base for federal army helicopters that bombed Chechnya and a military garrison. However on the airfield there were only two helicopters and the garrison organized a fierce resistance, after which the fighters entered the city in order to take hostages and that way to secure a safe passage to Chechnya.

31. Like the statement made by AsIan Mashadov (the Chief of staff of the Chechen military formations during the war and presently a likely candidate for presidency in the upcoming elections) when he referred to the Dagestan city of Hasavyurt as "the ancient Vainakh land."

32. In the city of Hasavyurt the Chechens make up 32 percent of the population and in the Hasavyurt district-25 percent.

33. The members of Nonviolence InternationalNIS society repeatedly observed, that akkinChechens say "we" regarding the people of Dagestan and "they" about
Chechens living in Chechnya. We believe this isa very interesting and indicative fact.

34. If the person lives in the southern part of Dagestan, it is enough to present his passport with the residence permit to cross the border.

35. Besides that, in the middle of1995 the city authorities in Hasavyurt, where the largest number of refugees came from, demanded that all men aged 16 and over must register at the city militia. Later this decision was reversed, bu $\mathrm{t}$ it also deterred people from getting registered.

36. 2,465 rubles is the equivalent of U.s. \$0.400.50 . This is just enough to buy one loaf of bread.

37. Ethnic "Dagestanis" have very strong family ties, what is known as "tuhumstvo." When a family is large, when some relatives hold important positions in power structures, these people try to find a good jobfor other relatives, they protect them, help them, etc. Russians, living in Dagestan usually have smallfamilies, weak relationships among relatives, they don't support each other the way Dagestanis do, that is why they became the most vulnerable ethnic group in time of economic and political crisis.

38. We mean the Kizlyar and Tarumovski districts of Dagestan.

39. Dagestan stands second to the last among the Russian regions byits living standard.

40. Unfortunately there is no direct-dial phone service to Kizlyar, you have to call through an operator. Nonviolence InternationalNIS is also planning to organize an email address in Kizlyar, that will help in communications with the "Medik" Fund. L

Refuge, Vol. 17, No. 2 (April 1998)

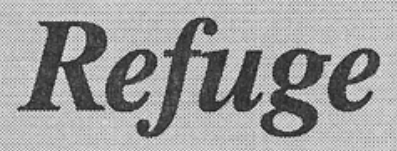

Canada's Periodical on Refugees Available from: Centre for Refugee Studies

Fax: (416) 736-5837

Email:refuge@yorku.ca http://www.yorku.ca/research/crs

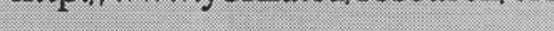

